\title{
Passen en meten
}

Citation for published version (APA):

van der Heijde, D. M. F. M. (2002). Passen en meten. Maastricht University. https://doi.org/10.26481/spe.20020308dh

Document status and date:

Published: 08/03/2002

DOI:

$10.26481 /$ spe.20020308dh

Document Version:

Publisher's PDF, also known as Version of record

\section{Please check the document version of this publication:}

- A submitted manuscript is the version of the article upon submission and before peer-review. There can be important differences between the submitted version and the official published version of record.

People interested in the research are advised to contact the author for the final version of the publication, or visit the DOI to the publisher's website.

- The final author version and the galley proof are versions of the publication after peer review.

- The final published version features the final layout of the paper including the volume, issue and page numbers.

Link to publication

\footnotetext{
General rights rights.

- You may freely distribute the URL identifying the publication in the public portal. please follow below link for the End User Agreement:

www.umlib.nl/taverne-license

Take down policy

If you believe that this document breaches copyright please contact us at:

repository@maastrichtuniversity.nl

providing details and we will investigate your claim.
}

Copyright and moral rights for the publications made accessible in the public portal are retained by the authors and/or other copyright owners and it is a condition of accessing publications that users recognise and abide by the legal requirements associated with these

- Users may download and print one copy of any publication from the public portal for the purpose of private study or research.

- You may not further distribute the material or use it for any profit-making activity or commercial gain

If the publication is distributed under the terms of Article $25 \mathrm{fa}$ of the Dutch Copyright Act, indicated by the "Taverne" license above, 


\section{Passen en meten inaugurele rede}




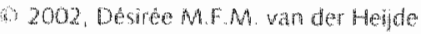
ISBN $905278342 \mathrm{~K}$ 


\section{Passen en meten inaugurele rede}

Rede witgesproken bij de aanvaarding van het ambt wan Hoogleraar in Outcome Assessment in Musculoskeletal Disorders ann de Faculteit Geneeskunde van de Universiteit Maastricht op wijdag 8 maart 2002 door

Dr. DMFM. van der Heide

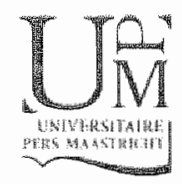

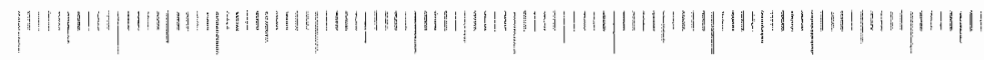



Mijnheer de Rector Magnificus, Zeer geachte dames en heren.

Passen en meten. dat is het motto van deze middag.

Vandaag zal ik met het uitspreken van deze rede het ambtaanvaarden van hoogleraar, en wel op internationale vrouwendag. Dezelfde dag waarop ik elf jaar geleden minn proefschrift verdedigde. Min leeropdracht is 'Outcome assessment in musculoskeletal disorders'. Ik hoop er in te slagen u een idee te geven wat net deze weidse beschriving bedoeld wordt. Het is een bijzondere leerstoel gericht op wetenschappelijk onderzoek. Aan de diverse facetten wan onderzoek zal ik dan ook het grootste deel van mijn rede besteden. Echter ook patiëntenzorg en onderwils, alles geplaatst in het huidige maatschappelike klimaat zullen aan bod komen. De leerstoel is ingested binnen het onderzoeksinstituut ExTra (Extra en Transmurale zorg) aan de Faculteit Geneeskunde van de Universiteit Maastricht, ingebed in de vakgroep Interne Geneeskunde, in het bijzonder de werkgroep Reumatologie, van het academisch ziekenhuis Maastricht.

\section{Passen en meten}

De titel van de rede is zo gekozen omdat het binnen het onderzoek inderdaad vaak "passen en meten" is. Passen en meten om de onderzoeksideeën te verwezenliken, om het benadigde geld te vergaren, de geschikte medewerkers te vinden, alles uit te woeren binnen beperkte tijd en dit in de inmer veel te krappe behuizing. Om zo maar even met een paar knelpunten in huis te vallen. Daarnaast heeft de leerstoel alles met 'meten' te maken. Waarom een Engelse naam voor de leerstoel? De letterlijke Nederlandse vertaling 'uitkomstmelingen' dekt niet de voltedige lading van het Engelse 'outcome assessment'. Het begrip outcome behelst zowel het beloop er naar toe, als de witeindelijke uitkomst, het uiteindelike resultat. Terwijl met 'assessment' zowel de maten, de instrumenten als ook het meten zelf en bovendien de hele methodologie van het meten bedoeld wordt. Tijdens deze rede zal ik voornamelik de veelomvattende Engelse begrippen gebruiken. 


\section{Oufcome}

Laten we numin leeropdracht: 'outcome assessment bij andoeningen wan het bevegingsaparaat nader bestuderen. Wat verstaan we onder 'outcome"? De beste omschrijwng hervan is m. . gegeven door de bekende epidemioloog Sacket, die de vakgroep hnterne Geneeskunde in het recente verleden met een bezoek vereerde. Dit is weergegeven in deze figur.

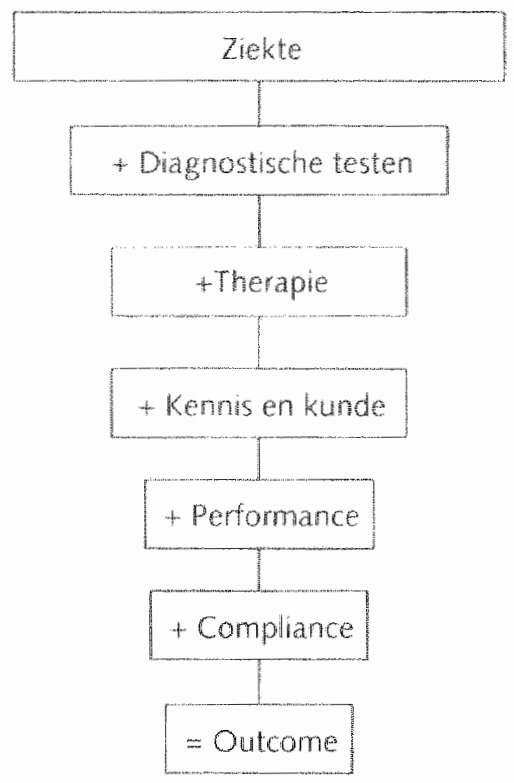

Outcome van een ziekte wordt door een combinatie wan factoren bepaald. Om te beginnen de arard wan de zlekte. Gevolgd door de mogehikheden om de ziekte te diagnosticeren en te behandelen. Maar alleen dan wordl de juiste diagnose gesteld en de beste therapie gegeven wanneer er voldoende kennis en kunde op dit terrein bij de arts anwezig is. Bowendien moet die kennis en wardigheid niet alleen aanwezig zijn, maar ook werkelik toegepast worden. Dit word meestal met de Engelse tem performance angegever. Tot slot hangt de uteindelike outcome ook al van de mate warrin de patient zich aan de voorschrif. 
ten houdt (compliance). Al deze aspecten zijn onderwerp wan eigen onderzok geweest in het recente verleden, en zullen dit ook in de nabije toekomstzijn.

Het onderzoeksgebied ingt op het terrein van aandoeningen wan het bewegingsapparat. Dit is maatschappelik gezien een zeer relevante groep aandoeningen. Van de mensen die in de WAO terecht komen hebben $30 \%$ klachten van spieren en gewrichten, hierbij de trauma's nog witgesloten. Dit is de tweede meest frequente oorzaak van instroom in de WAO. Ook bij de kosten van de gezondheidszorg staan aandoeningen van het bewegingsapparaat op de tweede plats met een jaarlikse uitgave van 1,3 miljard Euro. Het belang komt eveneens tot uiting in het aantal consulten bij de huisarts: leder jaar bezoekt ongeveer $11 \%$ van de patienten hun huisarts in verband met een nieuw probleem op het gebied van het bewegingsapparaat en $8 \%$ woor een terugkerende klacht. Binnen dit geheel van a.andoeningen nemen de ontstekingsziekten wan het bewegingsapparaat qua aantal een relatief kleine plats in. Echter omdat het chronische aandoeningen zijn met een lange ziekteduur, die bovendien vaker voorkomen op oudere leeftijd, zal het relatieve aandeel met de vergrijzing alleen mat toenemen. Daarnaast zijn het ziekten die vaak gepaard gaan met grote gevolgen voor het fysiek functioneren en de kwaliteit van leven. Daarom vormen ze een belangrijk onderwerp wan studie. Van onderzoek bij reumatische ontstekingsziekten zal ik verder in deze rede enkele voorbeelden geven.

Geschiedenis van het meten van lichaamstemperatuur

Laten we nu de methodologie van het meten eens in een historisch perspectief plaatsen. Het verrichten van metingen is niet iets nieuws van deze tijd. Als voorbeeld wil ik u de geschiedenis van het meten van de lichaamstemperatuur vertellen. Al ten tijde van Hippocrates werd het belang van lichaamstemperatuur erkend. Er bestonden echter geen mogelijkheden om dit te kwantificeren. Pas in $1592 \mathrm{kwam}$ daar verandering in, toen Galileo een instrument ontwikkelde om temperatuur te meten. Dit vond rooit toepassing binnen de geneeskunde. Het door hem ontwikkelde instrument kon alleen grove temperatuurswerschillen meten en was afhankelik wan het weer en de atmosfeer. Een essentiele 
stap werd gezet door Christian Huygens. Hij stelde in 1665 voor om een vaste schaal te gebruken met als ondergrens het vriespunt van water angegeven met 0 en als bowengrens het kookpunt van water an. gegeven met 100. De schaalverdeling was in centigraden. Gabriel Fabrentheit wilde een meer gedetalleerd systeem dat ook lagere temperaturen kon meten. Hij gebrukte darom als ondergrens het vriespunt van een mengsel van water met zout. De schaalverdeling was ook veel fijner waardoor kleinere veranderingen gemeten konden worden Bovendien stelde hij voor on kwik te gebruken in plats van water. hetgeen het meten aanzienlik versmelde. De vooraanstaand medicus Herman Boehazve, een tijdgenoot van Huygens, doorzag het kinisch nut van de thermometer en begon het te gebruiken in de kliniek Omdat we studenten wan Boerhave zich over Europa werspreidden. kreeg de techniek van het meten van de temperatuur bij zieken brede aandacht. Het duurde echter een eeuw voordat de thermometer een vaste plats $\mathrm{kreeg}$ binmen de geneeskunde. In 1742 herntroduceerde de Zweedse astronoom Anders Celsius de centigraden schaal in de klinische praktik. Zinn nam is nog steeds a an de schaalverdeling verbonden. Ook de technische mogelijkheden van de thermometer werden verder verbeterd. Daardoor was de toepasbaarheid groter en konden belangrijke ontdekkingen gedaan worden. Zo ontdekte Wunderlich medio 19 " eeuw dat koorts niet een ziekte op zichzel, maar een symptoom wan vele ziektes was. Hij stelde dan ook opnieuw dat het meten van de lichaamstemperatuur een belangrijk onderdeel van het onderzoek was. Toch werd het nog niet door veel artsen toegepast. Dit is ook deels te begrijpen als je op de hoogte bent van de gecompliceerdheid van het meten. De eerste commercieel beschikbare thermometers waren lange, makkelijk breekbare glazen instrumenten, die bovendien dutu waren en moeilijk te hanteren. Het duurde niet minder dan $25 \mathrm{mi}-$ nuten om de temperatuur te meten. Midden $19^{\circ}$ eeuw werd de nu nog bekende kwikthermometer ontwikkeld, die veel gebruikswriendelijker was en daardoor wid verbreide toepassing vond.

De geschiedenis van de ontwikkeling van het meten wan de lichadmstemperatur illustreerli een aantal zaken die ook nu nog gelden bij het ontwikkelen van nieuwe metingen en meetmethoden. Het begint met het concept dat cen gegeven van belang is om te meten, in het voorbeeld de lichaamstemperatuur. Daama moet een meetinstrument ontwikkeld worden. Hierbij is van belang dat je inderdaad meet 
wat je wilt meten, namelik de lichaamstemperatuur en bijvoorbeeld niet de omgevingstemperatuur. De verschillen die van belang zijn moew ten vastgesteld kunnen worden en ook binnen het meetgebied dat van belang is. Hier lagen de verschillen van inzicht tussen Huygens later Celsus en Fahremheit. Een ander zeer belangrijk aspect is de haalbaarheid. Het instrument moet bijvoorbeeld toepasbaar zin in de situatie waarin je het wilt gebruiken, makkelijk hanteerbaar en niet te duur zinn. Dit is essentieel voor het accepteren en daarmee ook toepassen wan het instrument. In het bovenstaande voorbeeld niet duidelijk aan bod gekomen, maar wezenlijk bij meten, is de reproduceerbaarheid. Indien je twee keer hetzelfde meet zonder dat de situatie veranderd is, moet je ook twee keer (ongeveer) hetzelfde antwoord krigen.

Een themometer is wat de meeste mensen onder een typisch meetinstrument verstaan. Echter er zijn ook andere soorten meetinstrumenten waarbij u misschien niet direct de associatie met een instrument maakt. Het kan bijvoorbeeld om een enkele vraag of een combinatie van vragen in een vragenlijst gaan. Ook voor dit type instrumenten, gelden dezelfde voorwaarden als boven gescheist. Samengevat, moeten alle instrumenten de volgende drie kwaliteiten bezitien: waarheid. het instrument moet meten wat het geacht wordt te meten: onderscheidend vermogen, er moet een onderscheid gemaakt kunnen worden tussen twee personen of groepen personen die verschillend zijn en binnen een en dezelfde persoon indien er een verandering opgetreden is; en tenslotte haabaarheid, het instrument moet brukbatar zinn in de situatie waarin het toegepast moet worden. Andere termen die in dit kader ook gebrukt worden zijn 'validiteit': een overkoepelende term voor de bovengeschetste kwaliteiten, en 'standaardisatie', ofwel afspreken dat dezelfde instrumenten gebruikt worden en bovendien op dezelfde wijze.

\section{VAS}

In de volgende tien minuten wil ik twee voorbeelden uitdiepen die illustreren welke aspecten aan bod kunnen komen bij de methodologie van het meten en hoe deze instrumenten toegepast kunner worden bij verder onderzock.

Bij andoeningen van het bewegingsapparaat wordt veel gebruik 
gemaakt van wragenligten die de patienten zelf kunnen invullen. Het verzamelen wan de antwoorden op de vragen kan op diverse manieren. De meest gebrukte manier is de 'visual analogue scale'. kortweg VAS genoemd. Dit is een lintje van $100 \mathrm{~mm}$ zonder schaalaanduiding. Alleen aan het einde worden ankers aangegeven, in het woorbeeld wan pijn is dit 'geen piin' en 'ondraaglijke pijn'. De patient moet met een streepje de mate van pijn aangeven. De af́stand van links tot aan de door de patiënt aangegeven markering wordt gemeten in millimeters.

Er zijn diverse redenen die hebben bijgedragen aan de populariteit wan de VAS. Het is in veel omstandigheden te gebruken, er bestaan weinig problemen bil het vertalen, het kan gemakkelik en snel ingevuld worden met weing instructie. Het intuitief meest aantrekkelikk van de VAS is hetgrote aantal antwoordcategorieen. Theoretisch zijn er namelijk 101 mogelijke antwoorden. Hierdoorkan de patient precies aangeven hoeveel pijn hij ervaart. De VAS zou hiermee ook gevoeliger zijn om veranderingen op te pikken dan een schaal met minder antwoordmogelijkheden. Dit alles lijkt echter mooier dan het in werkelijkheid is. Uit onderzoek binnen de psychologie is gebleken dat het menselijk brein slechts ongeveer 7 verschillende toestanden kan onderscheiden, dus niet de 101 mogelijke antwoorden op een VAS.

De patiênten kunnen de hele lijn voor hun antwoorden gebruiken. Het blijkt echter uit onderzoek dat er een voorkeurslocatie voor het geven van eem antwoord is rond de zogenaamde 'gouden sectie'. Deze ligt op $62 \%$ gemeten vanaf de positieve zijde. in het voorbeeld 'geen piin' dus bil $62 \mathrm{~mm}$. De kans dat een patiënt een antwoord geeft rond 62 is dus duidelijk groter dan dat het antwoord 50 of 75 is. Het blijkt ook dat mensen verschillende waardes geven aan dezelfde ervaring. Bij een proef warbij geluiden met verschillende geluidssterktes werden aangeboden, geven de proefpersonen dezelfde volgorde aan, maar op een verschillend gedeelte van de schaal. De grootste verschillen tussen de proefpersonen doen zich voor aan het rechtereinde van de schaal bij 'het hardst mogelijke geluid'. Indien de proefpersonen vooraf een geluid kregen dat gedefinieerd werd als 'het hardst mogelike geluid", na. men de verschillen tussen de proefpersonen duidelijk at. Aan de linkerkant van de schaal doet dit probleem zich veel minder voor. Het is veelal helder wat verstaan wordt onder 'geen geluid' of 'geen pijn'. Uit dilt en ander onderzoek blijkt dat met name de rechterzijde van de schal niet woor iedereen dezelfde betekenis heeft, met andere woor- 
den twee patienten die beide 70 scoren kumen toch een verschillendte ermst in pijn ervaren.

De VAS likt een continue, lineaire maat die werkt zoals het meetatje, dat u op de omslag van mijn gedrukte rede kuntzien. Met die veronderstelling worden de gegevens ook geanalyseerd. Dat betekent dat de VAS aan de voorwaarde moet voldoen vam een lineaire schaal, namelik dat de atstanden tussen de categorieèn geligk zijn (denk aan het meetlatje). Indien een patiënt op de schaal wan 10 naar 20 gaat is dit een even grote verslechtering als van 78 naar 88 . Het is echter gebleken dat de schaal eigenlijk alleen in het midden lineair is. Vooral de verandering die plaats kan winden aan de rechterkant van de schaal is sterk afhank. elijk van de plaats die bij het eerste antwoord gegeven is.

Deze gegewens uit de literatuur spoorden ons aan om een onderzoek uit te voeren bij een veelgebruikte vragenlijst naar het fysiek functioneren van patiënten met de ziekte wan Bechterew, de BASH (Bath Ankylosing Spondylitis Functional Index). De ziekte van Bechterew. ook spondylitis ankylopoetica of in het Engels ankylosing spondyliks (AS) genoemd is een ontstekingsziekte wan vooral de wervelkolom, mees: beginnend bijonge mannen. De BASFl bestaat uit 10 vragen die op een VAS beantwoord worden. Wij wilden twee onderzoeksvragen beantwoorden: 1) gebruiken de patienten alle 101 mogelijkheden van de VAS; 2 ) is de VAS een lineaire schaal (met gelike afstanden over het hele bereik van de schaal) of een ordinale schaal (waarbij antwoorden alleen in de juiste volgorde van ernst worden aangegeven; in het voorbeeld 20 is slechter dan 10 en 88 is slechter dan 78 , malar je kunt niet zeggen dat beide patiënten evenveel verslechterd zijn).

Het bleek dat wrigwel alle informatie behouden bleef indien de ant. woorden in 5 groepen verdeeld werden. Dus de VAS functioneert als een 5 -puntsschaal in plaats wan de verwachte 101 -puntsschaal. Bovendien bleken de afstanden tussen de groepen niet gelijk te zijn. Dus de WAS kan niet als een lineare schal mar moet als een ordinale schaal geinterpreteerd worden. Wat betekent dit nu? Ten eerste kunen we met veel minder antwoordcategorieen toe, zonder verlies van informa. tie. Ten tweede kan een verandering die in getal gelijk is, een verschil in ervaren pijn vertegenwoordigen. Dus de patient die van 20 naar 10 verbetert, zou wel eens een grotere afname van pin kunnen hebben. dan de patient die van 88 naar 78 ging lof juist kleiner). Ten derde is de meestal toegepaste statistiek woor de analyse van een VAS in feite voor 
Theare schaten en dus niet correct. Tenslotte wordt binnen de reumatologie veel gebruk gemaakt vaneen percentage verbetering. bijvoorbeeld een verbetering van $20 \%$. Het hangt dus sterk var de plats van het eerste antwoord af wat de precieze betekenis is en dit is niet zomaar vergelijkbar tussen patienten. Een verandering van $20 \%$ bij de ene patient is net dezelfde verandering als $20 \%$ bij een andere patient.

Bovenstande is en uitgebreide uiteenzelting over de methodologite rond het meten. Dit onderzock werd uitgevoerd bil een reumatische ontstekingszickte. Uit gegevens wan de literatuur en ander eigen onderzoek blikt dit problecm niet specifiek voor deze vragenlijst of ziekte te zijn, maar gaat het om een probleem dat generaliseerbaar is naar het gebruik van een VAS in vele situaties.

\section{Röntgen}

Een tweede voorbeeld uit eigen onderzoek wil ik inleiden met opnieuw een stukje geschiedenis. Een voor de verdere ontwikkeling wan de geneeskunde (en ook voor mij persoontijk) belangrijke ontdekking was die door Wihelm Conrad Röntgen. Deze Duttse natuurkundige ont dekte in 1895 een tot dan toe onbekende soort stralen. Aanwankelik werden ze X-stralen genoemd, maar ze werden algemeen bekend onder de naam röntgenstralen. Het zijn elektromagnetische stralen die ontstaan als gevolg wan de wisselwerking van energierigke deeltjes (bijv. elektronen) met materie. In 1901 kreeg Röntgen de (in dat jaar voor het eerst toegekende) Nobelprijs voor natuurkunde. Röntgenstraling dringt door alle stoffen heen, waarbij door absorptie een deel van de stralen verloren gaat. Doordat röntgenstralen in diverse weefsels een verschillend doordringingsvermogen hebben, maken deze stralen het mogelik structuurveranderingen daatin als schaduwen af te beelden op een scherm of af te drukken op papier, c.q. film. Het orgaanstel. sel warin de meeste straling an de bundel wordt onttrokken, is het benige skelet (door het hoge kalkgehalte). Deze foto aat de hand met de trouwring zien van de vrouw van Röntgen.

Een zeer getalenteerde vrouw die onderzoek deed met radioacheve stralen was Marie Curie. Zij was dan ook de eerste persoon die tweemaal de Nobelprijs ontving, en de eerste vrouwelike hoogleratr die aan de Sorbonne doceerde. Uiteindefilk stierf zij aan de gevolgen van 
leukemie ontstaan als gevolg van de vele experimenten dis zil deed met radioactieve stralen. In de begintijd ging ook het maken van röntgenfoto's nog gepard met hoge stralenbelasting. Tegenwoordig is dat zeer sterk afgenomen en leveren röntgenfoto's slechts een geringe stralenbelasting.

Zoals gesteld, is in het kader van 'outcome assessment' het ontwikkelen, het valideren, en standaardiseren van meetinstrumenten van groot belang. Daama kunnen ze gebruikt worden om het beloopen de prognose van klachten en symptomen vast te stellen, evenals het bepalen van de effectivteit van therapie. Zo is de schade die vastgesteld kan worden op rönlgenfoto's een belangrijke maat om de ernst en uitgebreidheid wan chronisch gewrichtsreuma te bepalen. Chronisch gew wrichtsreuma (reumatoide artritis of kortweg RA) is een ziekte warabij de ontstekingen van de gewrichten op de woorgrond staan. Als gevolg van deze ontstekingen ontstat er schade aan gewrichtsstructuren zoals kraakbeen en onderliggend bot. Dit kun je zien op röntgenfoto's van handen en voeten. Om dit in maat en getaluit te kunnen drukken is een scoringsmethode on wikkeld door Sharp. Tijdens mijn promotieonderzoek in Nijmegen heb ik dit verder ontwikkeld en gevalideerd. Dit heeft geleid tot de gemodificeerde Sharp methode. Deze methode kwantificeert defecten ontstaan in kraakbeen en onderliggend bot, de zogenaamde erasies, en verlies van kraakbeen zichtbaar als gewrichtsspleetversmalling. Door toepassing van deze methode, in eigen en andemans onderzoek, zijn we meer te weten gekomen over de relatie van de actiwiteit van RA met het ontstaan van gewrichtsschade en over de relatie tussen het bestaan van gewrichtsschade en beperkingen in het functioneren. Daarnaast is de toepassing in het geneesmiddelenonderzoek bij RA van groot belang geworden. Er worden steeds meer geneesmiddelen ontwikkeld die het beloop van RA gunstig kumnen beinvloeden. Hierbij is het verminderen en bij wookeur woorkomen van gewrichtsschade van imminente waarde Mogelijk zou er zelfs herstel kumerioptreden van reeds ontstane schade. Om dit aan te tonen moet je naar specifieke tekenen van herstel kijken. Momenteel zijn we met een internationale groep bezig om hiervoor een methode te ontwikkelen. De gemodificeerde Sharp methode is een illustratie wan hoe een instrument op meerdere terreinen ingezet kan worden. Namelik om meer te weten te komen over de pathofysiologie, het beloop. en de outcome var RA, evenals de effectiviteit van therapie. 
Het onderzock van outcome assessment heeft een bij utstek internationaal karakter. Meetinstrumenten hebben vooral nut indien ze wijd toegepast worden. Alleen als onderzoekers uit verschillende lan. den, dezalfde meetinstrumenten in hun onderzoek toepassen, kumen de resultaten vergeleken worden. Daarom is het ook zeer de moeite waard om veel energie te steken in het internationaal standaardiseren van meetinstrumenten. Ook hierin speelt onze afdeling een vooraan. staande rol, en wel met name op het terrein van de reeds cerder genoemde ziekte van Bechterew. Vanuit Maastricht hebben we internationale onderzoekers werkzaam op dit gebied, bijelkaar gebracht in de ASAS werkgroep. ASAS is een acroniem voor ASsessments in Ankylosing Spondylitis. Sinds 1995 vinden frequente bijeenkomsten plats die geleid hebben tot een set van meetinstrumenten die nu bij ieder onderzoek met AS toegepast worden. Om voor AS nieuwe meetinstrumenten te kunnen ontwikkelen, zijn we in 1996 gestart met het volgens een vast protocol volgen van rum 200 patienten met AS in Maastricht, Sittard, Gent en Parijs in het OASIS onderzoek, de Outcome in Ankylosing Spondylitis International Study. Samen met de onderzoeken die nu plaatsvinden naar het effect van nieuwe medicinen. levert dit cen schat aan gegevens op over het klinisch beloop. schade op rontgenfoto's en de MRI scan. Vooral dit laatste onderzoek levert informatie over de ziekte op, die voorheen niet op andere wijze te verkrijgen was. Al deze gegevens zullen de komende jaren gebruikt worden voor het verder onderzoek naar metingen bij AS.

Samenvattend, deels voortvloeiend uit de woorbeelden die ik u toonde, deels nieuw voor $u$, zal het onderzoek zich de komende jaren richten op de volgende onderwerpen:

Om te beginmen de methodologie van meetinstrumenten bij ziekten van het bewegingsapparaat. Dit betreft basaal onderzoek samenhangend met de ontwikkeling en validatie wan nieuwe meetinstrumenter. Als voorbeeld kunt $U$ denken aan instrumenten om kwaliteit van leven te meten bij specifieke aandoeningen wan het bewegingsappa. rat. Vervolgens het valideren van bestaande meetinstrumenten voor gebruik bij een andere diagnose, in een andere taal of in een andere klimische setting (bijvoorbeeld specialist of huisarts). Ook hel ontwikkelen yan nieuwe meetinstrumenten waar deze ontbreken, behoort tot het onderzoekspakket. Daamaast zal aandacht besteed worden aan 
het standaardiseren van meetinstrumenten en het samenstellen van sets van meetinstrumenten die internationaal in elk onderzoek bij die aandoening gebruikt dienen te worden. Dit is van belang om vergelijkend onderzok en meta-analyses te bevorderen. Tevens zal aandacht besteed worden aan het on wikkelen en valideren van criteria om een respons op een interventie vast te stellen. Tenslotte zullen de nieuw ontwikkelde en gevalideerde meetinstrumenten toegepast worden om het beloop, de klinische consequenties en de prognose van andoeningen van het bewegingsapparat te meten. Hieronder vallen onder andere de socio-economische gevolgen van een bepaalde aandoening. Bij toepassing van de instrumenten zal het zowel om de effectiviteit als de kosteneffectiviteit van interventies gaan. Het moge duidelijk zijn dal er bij deze thema's overlap en samenwerking is met diverse disciplines. Met name noem ik hier de klinische epidemiologie. MTA en huisartsge neeskunde.

\section{Onderzoek in de knel}

Hoe zit het nu met de randvoorwaarden waarbinnen het onderzoek plaatsvindt? Het klinisch wetenschappelijk onderzoek op het gebied van de geneeskunde wordt meestal uitgevoerd door artsen werkzaam in het academisch ziekenhuis. Deze artsen hebben dan 3 taken: patiëntenzorg, onderwijs en onderzoek. Het principe dat deze taken door dezelfde personen worden gedaan, heeft zeker voordelen. Het zelf onderhouden van patiëntencontacten heeft een gunstige weerslag op het formuleren van de juiste onderzoeksvragen, en kan onderwijs aan studenten verlevendigen. Ook het zelf uitvoeren van onderzoek kan positieve gevolgen hebben op het toepassen van de gevonden resultaten in de klinische praktijk en het aanleren van een kritisch wetenschappelike houding bij studenten. In de combinatie zit echter ook eern gevaar. Alleen een schaap met vij poten is in staat om al deze taken op topniveau uit te oefenen binnen de gegeven tijd. Het ligt dan ook veel meer voor de hand orn mar de voorkeur van de artsen te kijken en dat ieder zich op bijvoorbeeld twee taken toelegt. Door de overlappende activiteiten van de collega's blijven kruisbestuivingen toch gewaarborgd, terwijl er een grotere mate van efficièntie, kwaliteil en arbeidssatisfactie kan optreden. Kortom: zet mensen in op het gebied van hun 
grootste talenten. Een yoowarde is dan wel dat in ledere tak van sport carriere gemakt moet kunnen worden. Topprestaties moeten beloond worden, ongeacht of deze op het terrein van patientenzorg, anderwijs of onderzoek liggen.

Het a anwezig zim van de taken patientenzorg, onderwijs en onderzok binnen een academisch ziekenhuis, ook indien niet perse uitgevoerd door enzelfde persoon, brengt het risico van verdringing met zich mee. Hierbij krijgt patientenzorg steeds prioriteit: we leven in een maatschappij waar voldaan wordt aan de vraag naar zorg. Slechts zelden wordthagegaan of de vrag naar zorg terecht en zinvol is. Alleen al het uitspreken van deze twiffel is gevaarliken vooral politiek onverantwoord. De wraag naar zorg neemt zorgwekkend toe. Om dicht bij huis te blijven, alleen al het aantal nieuwe patiënten dat zich meidt op de poli reumatologie van het azM liet in 7 jaar tijd een toename van $51 \%$ zien. En de laatste jaren is er een jaarlijkse stijging van $10 \%$. Dit terwil het aantal patienten met reumatische aandoeningen in engere zin, zo* als de reumatische ontsikangsziekten onveranderd is gebleven. Als gevolg van de vergrijzing, en het feit dat aandoeningen wan het bewegingsapparaat waker voorkomen op oudere leeftijd. kan de komende Jaren alleen een nog sterkere stiging verwacht worden. Deze toename in waag heeft overigens niet geleid tot personele uitbreiding. Binnen het onderwils staan eveneens grote veranderingen op stapel, die ook een verwwaring van de onderwijslast inhouden. Zo is er een nieuw curriculum in ontwikkeling waabij de reumatologie in het derde jaar een intensieve rol gaal spelen. Door het praktikgerichte karakter zal de be. lasting voor de climici sterk toenemen. Dit zal in 2003 beginnen, evenals de fors veranderde co-schappen, waarbil oude en nieuwe stijl elkar een jaar zullen overlappen. Deze vernieuwingen hebben verstrekkende gevolgen voor de personele belasting: voor het ontwikkelen is nu at veel formatie nodig en voor het uilvoeren en toetsen vanaf wolgend jaar nog meer. Dit zal slechts zeer ten dele op valkgroep-c.q. werkgroepriveau gecompenseerd worden met extra fomatie. $U$ begript dus war het knelpunt zit. Er is meer tijd nodig voor patientenzorg en onderwils. geen verandering in personele bezetting, en dus bij ongewizigd beleid minder tij voor onderzoek. 


\section{Index van uitgaven per sector en BNP}

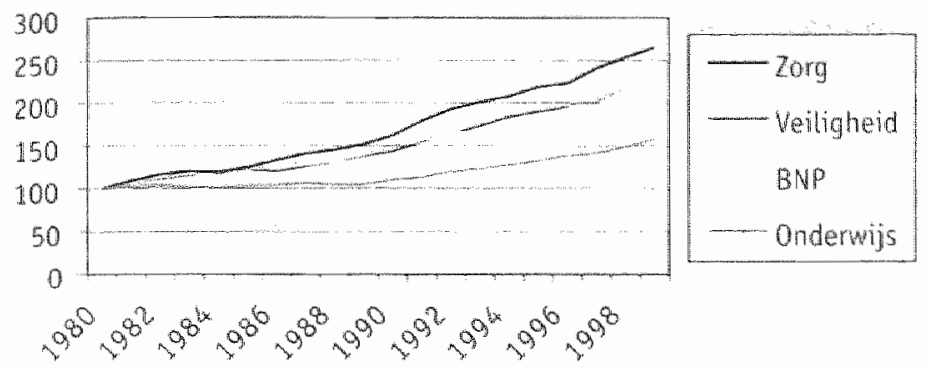

Index wan uitgaven per leerling/student:

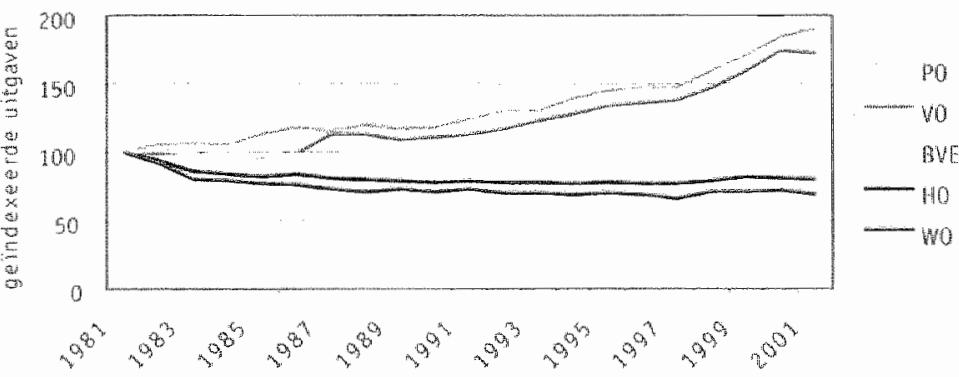

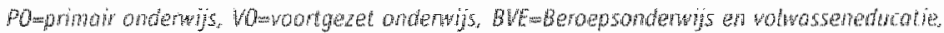

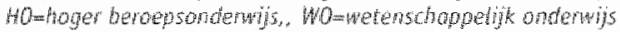

Dat de zorg de hoogste prioriteil, boven onderwijs en onderzoek, krijgt moge ook duidelijk zijn uit de volgende gegevens. Indien we kijken naar de uitgaven in Nederland, uitgedrukt als percentage van het bruto nationaal product (BNP), blikt dat de investering in zorg relatief loege. nomen is ten opzichte van het BNP terwil het onderwijs fors achterblift. Deze gegevens zin afkomstig uit de door de verenging van universitehten in 2001 opgestelde position paper 'Kennis voor kansen'. Hienin wordt gesteld dat een grote investering nodig is voor zowel hoger en wetenschappelijk onderwijs als onderzoek, indien Nederland niet de boot wil missen van de kenniseconomir. Ook voor het oplossen wan 
matschappelike problemen is kennis essentieel. Het bijkt echter dat de investering in Nederland in 'kemnis' sterk achtergebleven is. De titel van het rappont zou dus ook omgedradid kunnen worden in 'Kans voor kennis'. Onderstaande gegevens putten veelal uit deze prima position paper.

Hebben we net kunnen concluderen dal de investering in ondewijs sterk achtergebleven is, dan blijkt bovendien bij nadere bestudering dat het met name het wetenschappelijk onderwijs gevolgd door het hoger onderwijs, hierwan de dupe geworden is.

Tot zover patientenzorgen onderwijs. Hoe zit het dan met de investering in onderzoek? Hierbij is het interessant om dit te vergelijken met gegevens wan de OESO-landen KOrganisatie voor Economische Samenwerking en Ontwikkeling). Ook dan blikt weer dat er de laatste decade in Nederland een afname van investering in onderzoek is geweest uitgedruki als percentage van het BNP. Bovendien lagen deze uitgaven al veel lager dan andere landen. Vooral het verschil met lapan en de Verenigde Staten is groot.

Irvesteringen in R\&D in \% wan het BNP

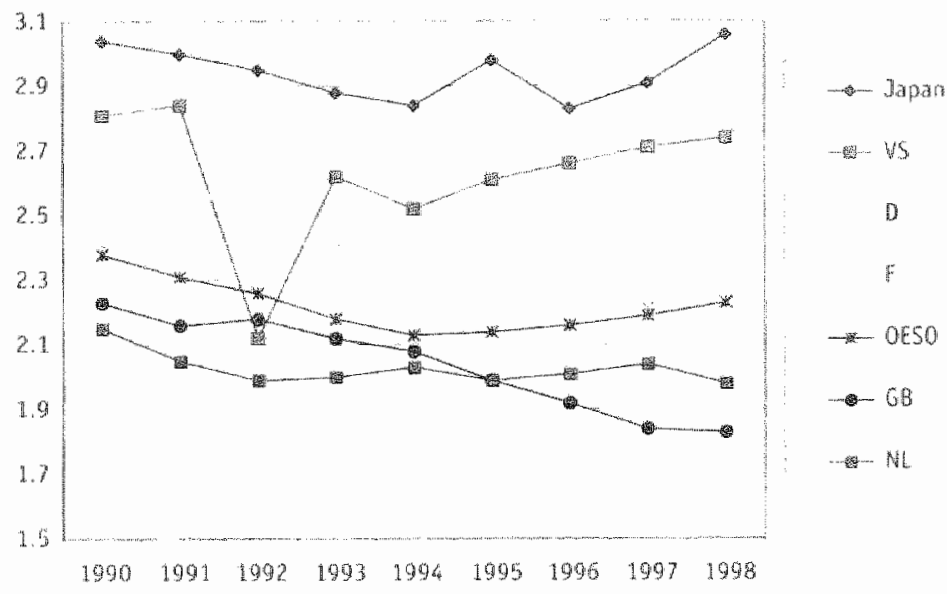


Naast de uitgaven gerelateerd aan het BNP, kun je ook een vergehijking maken tussen de inzet van het aantal onderzokers per 10000 personen wan de beroepsbevolking in de verschillende landen. Opnieuw ean niet vrolik stemmend beeld: Nederland is bijna de hekkensluiter alleen oostenrik, Spanje. Hongarije, en Portugal scoren nog lager.

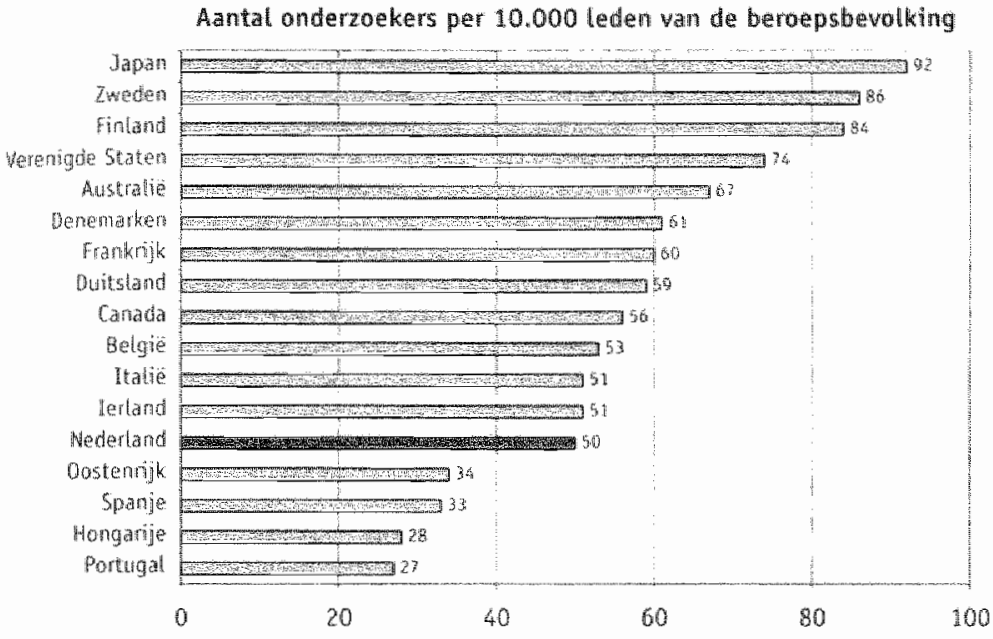

Er moet dus duidelijk een ander beleid ingezet worden. Meer geld moet beschikbaar komen voor ondarwijs, met name het hoger en weten. schappelijk onderwijs, en voor onderzoek. Laten we een positieve instelling ten toon spreiden en annemen dat dat gebeurt. Hoe zit het dan met het personeel? Hier is een ander belangrijk knelpunt. Er is een groot tekort aan alsen dat in een rap tempo ontstaan is. Het ziet er niet naar uit dat er binnen korte tijd een oplossing voor komt. Wederom gaat hier de concurrentie spelen tussen patientenzorg en onderzoek. In de academische zickenthuizen wil men gragg talentwolle artsen inzathen in de drie taakgebieden. Echter de salariêring en arbeidsvoorwaarden zijn niet concurrerend met die in de private sector. Dit geldt zeker als je naar de inkomenspositie van onderzoekers kijkt. Om helemaal niet te spreken over de zeer lage betaling aan AIO's. Onderstande tabel illustreert dat er een duidelijke achterstand is indien de lonen in de totale collectieve sector en de subsector onderwijs en wetenschap vergeleken 
worden met de marktsector. Dit is onderverdeeld naar het opleidingsniveau van de medewerkers. Academici werkzam binnen wetenschap cn ondewijs verdienen $18 \%$ minder dan academici werkaam binnen demarktsector.

Procentude loonverehitem tusgen de markisector en de collectieve sedor, weergegewen per opteidingsniveaù (1997)

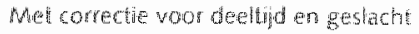

\section{Collectieve sector totat}

Paxsondamigs

$+3 \%$

Lataper onderwing

$\$ 3 \%$

Middusarar onderwitgr

$+4 \%$

Hoger beropsonderwits

$-5 \%$

Mezenschappelinc onderwigh

$-9 \%$

\section{Subsertor Onderwigs en Watenschappen}

Bustisonderwigs

$4.3 \%$

Laser onderwigs

$4 \%$

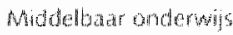

$\cdots 2 \%$

Hoger beropsonderwigs

$-7 \%$

Wetenshatprelite onderwils

$-18 \%$

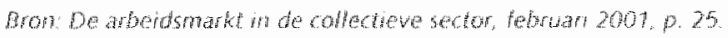

Zoals ook in het rappont "Kennis voor kansen" aangegeven moet er rumte gemaakt worden om de arbeidsvoorwaarden te moderniseren. Dit is hard nodig om te zorgen dat toptalenten aangetrokken en behouden kunnen worden woor de universiteiten en academische ziekenhuizen om het onderwijs en onderzoek op een hoog peil te houden en brengen. Dit moet bovendien snel gebeuren omdat binnen tien jaar eerderde deel van de wetenschappelije staf met pensioen gaat.

Na al deza negatieve punten, zou u kunnen denken dat de prestaties van het Nederlands onderzoek beneden aile peil zim. Gelukkig kan ik w daan geruststellem. Over het gehele terein vande wetenschap neemt Nederand met $2,55 \%$ van de wereldproductie van wetenschappelijke publicaties de achtste plats in. Corrigeren we dit voor het antal invoners, dan neemt Nederland samen met Canada de derde plaats in. De VSen Japan zakken dan van de eerste en tweede plats terug naar res- 
Percentage van de wereldproductie wan publicaties per land

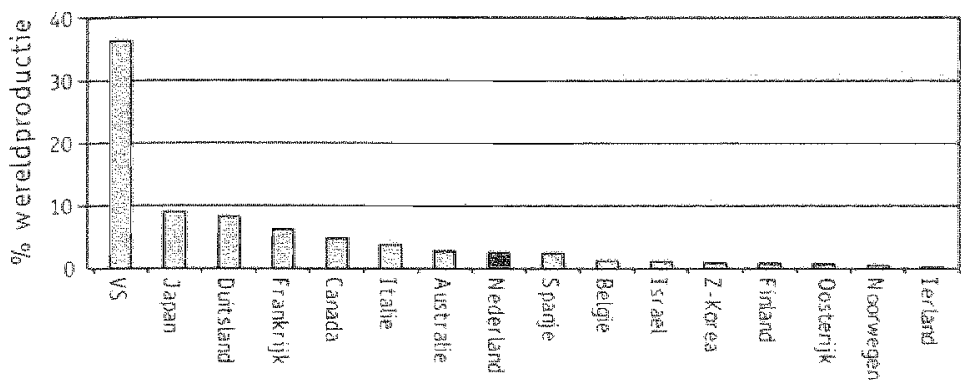

pectievelik de zevende en dertiende plaats. Publicaties in het veld van klinische geneeskunde vomen in dit geheel nog eens een positieve uitzondering met $3.2 \%$ van de weraldproductie.

Het is dit niveau dat in vele jaren is opgebouwd dat we graag willen behouden. Het opbouwen van een succesvolle onderzokshijn kost gemiddeld tien tot vijftien jaar. De uitstekende resultaten van nu, zeggen vooral veel over het velleden. We moeten goed voor ogen houden: 'The future is acting now'. Laten we alert zijn dat de voorwarden waarbinnen het onderzoek kan plaatsvinden een gunstige wending nemen. Want dames en heren, onderzoek doen is fantastisch. Ik zie mijn rede als geslaagd, indien ik een klein beetje van het enthousiasme voor het doen van onderzok heb weten over te brengen.

Zoals in het begin van mijn rede gezegd, is het vandagg internationale vrouwendag. Een aardige aanleiding om eens te kijken hoe het gesteld is met het aantal vrouwen in hogere posities binnen onze universiteit. Aan de UM is er een streven geformuleerd dat $25 \%$ van de posities op niveau van universitair hoofddocent en hooglerar in 2006 door een vrouw bezet moel zim. Momenteel zijn er 263 hoogleraren, de honorair hoogleraren buten beschouwing gelaten, warvan 12 vrouwen. ofwel een percentage van $4.5 \%$. Dus dames, nog voldoende uimte om te groelen. Het uitgangspunt is naturlijk wel dater op kennis en talent word geselecteend. Zo niet, dan dreig je als vroumelijke hooglerar wel in een eigenaardige, weederangs positie gemanoeuvreerd te worden. Het toekennen van bonussen bij instroom van wrow wen in hoge posities 
aan de Unversiteit van Amsterdam of boetes bij uitstroom bij de Katholicke Universiteit van Brabant, doen hiebij wel heel vreemd aan Onze sekse is niet zo bijzonder dat ze alleen met dit soort matatregelen een plek in een hoge wetenschappehke functie kan veroveren. Wel blijken er nog steeds voor vrouwen andere belemmeringen te bestaan dan voor mannen om door te stromen. Onderzoek naar deze belemmeringen en vervolgens de resultaten in beleid omzetten, zal de kansen voor vrouwen op een naturlike manier vergroten. Alleen al het beter gebruk maken van het aanwezige potentieel bij vrouwen, kan een belangrijk wapen zijn bij de bestrijding van het tekort aan personeel binnen de geneeskunde. 
Mijnheer de Rector Magnificus, dames en heren, dit brengt mil bij het laatste onderdeel van mijn rede: het dankwoord. Bij het doorlezen van andere redes, kwam ik vaak tegen dat dit kort gehouden werd, omdat uitgebreid bedanken niet bij de familietradite behoorde. of het bij namen noemen van personen het risico met zich meeneent dat iemand vergeten wordt. Ook in onze lamile is een uitgebreid bedanken geen gewoonte, en inderdaad het noemen van namen draagt een risico met zich mee. Toch wilk deze gelegenheid niet yoorbij laten gaan om min dank te uiten aan diegenen die het mede mogelijk gemakt hebben dat ik hier vandaag sta

De Stichting Wetenschapsbeoefening van de Universiteit Mastricht. het College wan Bestuur, en het bestur van de Faculteit Genceskunde dank ik voor het instellen van deze leerstoel. Hooggeleerde Knotherus, beste Andre, II was getuige van min allereerste stappen op onder. zoeksterrein in de hoedanigheid van lid van de beoordelingscommissie van de stimuleringsgelden voor kinisch onderzoek beschikbar gesteld door het rik. Sindsdien bliven onze wegen zich kruisen. Als directeur van het onderzoksinstituut ExTra was jij een van de belangrike initiathefnemers voor het instellen van mijn leerstoel. Als directeur van de onderzoeksschool CARE, waar ExTra deel van uitmaakt, blijven we nar ik hoop nog lang samenwerken. Hooggeleerde van Schayck, beste Onno, als huidige directeur van ExTra, valt mijn hoogleraaschap binnen jouw instituut. Jouw stimulerende, open houding maken het werken voor mij binnen ExTra zeer plezierg. Door jouw uitgebreide eigen evaring als onderzoeker zijn er vaak maar een paar woorden nodig om zaken rond het onderzoek te verduidelijken. Gragg zet ik onze wruchtbare samenwerking nog lang door. Hooggeleerde Hillen, beste Harry. is ben als reumatoloog werkaam bimen de inteme Geneskunde. waarvan jif de vakgroepvoorzitter bent. Dank aan jou voor het mede ondersteunen van het instellen van deze leerstoel en de wijheid die je lat om het onderzock te kunen uitvoeren. Hooggeleende vander linden. beste Sief. Jij wordt in dit rijte van personen die het hele proces van de aanvaag van de leertoel geiniteed heet, als latste persoon genoemd. De meest importante personen worden vale voor de climax beward. Ji bent onverstoorbaar, een man van weinig woorden. Sons 
likt het je aan daden te ontbreken. Dit is echter alleen maar schijn. Mi weet heel goed prioriteiten te stellen, hebt een heldere kijk op problemen en in de toekomst, en bent juist zeer daadkrachtig indien het erop aankomt lij hebt als geen ander begrepen dat je mij het meeste kon helpen, door mij mingang telaten gaan, stimulerend en adviserend op de achtergrond. Ik had geen betere superieur kunnen treffen. Sjef, laat dit wog veel jaren zo zijm.

Het Limburgs Universitair Centrum te Diepenbeek, met name de hooggeleerde rector Martens en de hooggeleerde Raus ben ik zeer erkentelijk dat ze mij een gastprofessoraat in Diepenbeek aanboden, nog woordat de leerstoel die vandaag in de belangstelling staat werd ingesteld. Het zou mij vreugde doen indien we deze vorm van samenwerking tussen het LUC en de Universiteit Mastricht nog gerume tijd kunnen continuerem.

Min opleiders in de Interne Geneeskunde en later de Reumatologie, de hooggeleerde heren van 't Laar en van de Putte, de weledelzeergeleerde heren Mattousch en de Rooij, hebben mij de liefde woor het vak bijgebracht en de basis gelegd voor mijn verdere ontwikkeling. De promotoren van min proefschrift, de hooggeleerde van de Putte, van Rijswijk. van Riel en van 't Hof, fullie hebben aan de wieg gestaan van mijn carriere als onderzoker. Het was een zeer prettige tijd, eentie waar ik nog vaak met een beetje heimwee aan terugdenk. Het onder zoek dat toen gestart is, de kennis over klinische epidemiologie en het uitwoeren van klinisch onderzoek, vormt het hart van de leerstoel die ik vandaag aanvaard. Piet, vooral onze leerstoelen en onderzoekslinen hebben parallellen. Daarom is ook nu nog vaak sprake van samenwerking. Mijn wens is dat dit ook in de toekomst zo zal zijn.

Minin directe collega's reumatologen, Sjef, Marike. Piet, Debby. Ro. bert. Anmelies. Moge een beetje van de eer die mij vandaag te beurt valt op jullie alstralen. Alleen mede dankzijullie, de collegialiteit, de inzet binnen patentenzorg en onderwis heb ik mij kunnen toeleggen op onderzoek. De samenwerking met de reumatologen in Heerlen en Sittard, Henk, Hary. Hille, Ralph, geefteen extra dimensie aan de reumatologische zorg, assistentenonderwis en onderzoek in het Zuid-Limburgse. Een verdere uktbouw van deze samenwerking zou ik van harte toejuichen 
De promovendi, Annelles, Erik, Smone, Anneke, Astrid, Karin, Lies. beth, Guy. Debby en Astrid, jullie maken het mogelijk dat de ideeen voor onderzoek ook concreet uitgevoerd worden. Ik hoop een beetje van het enthousiasme voor het doen wan onderzoek op jullie over te kunnen brengen. Zonder de hulp van de onderzoeksassistenten, de secretarele ondersteuning, de poliassistentie zou alles veel moeizamer gaan. Anita, Jolanda, Nicole. Mieke en Janine, Yolanda, Liesbeth an Peggy. Ellen, Maddy en Edith dank woor jullie ondersteuning.

U allen hier aanwezig wil ik hartelik danken dat U de moeite genomen heeft om naar Maastricht te komen om bij deze inauguratie aanwezig te zijn. Immers, in de praktijk blijkt de afstand tussen bijwoorbeeld Utrecht en Maastricht groter te zinn, dan andersom. Voor velen zal het ook passen en meten geweest zinn om de aanwezigheid mogellik te ma* ken.

Ik ben dankbaar dat zowel mijn ouders als schoonouders vandaag aan. wezig kunnen zijn.

Lieve ouders, jullie zijn het die letterijk en figurlijk aan de wieg gestaan hebben. De positieve effecten van een warm nest draag je steeds met je mee. Jullie hebben mij altijd onvoowatrdelijk gesteund, zowel moreel als ook daadwerkelijk met heel weel praktische zaken. Met een gerust hart laat ik de zorg van Féline en Maxime vaak aan jullie over. Deze dag drag ik aan julle op.

Dank aan alle familieleden, vrienden, buren, die steeds weer bereid ziln om de gaten die onvermijelik in het opvangnet valien. te dichten.

Tenslotte lieve Bram, Féline en Maxime. Hoe mooi deze dag en leerstoel ook, central in het leven zign je geliefden. Met jullie prijs ik mij heel gelukkig. Bram, de steun vanuit het thuistront is zeer belangrijk om carriere te kunnen maken. En dit geldt wellich nog meer voor een vrouw. Jil bent mijn grote steum en toeverlat. Liefste Bram, Feline en Maxime, zou je hel leven kunnen vergelijken met de Olympische Spelen, dan heb ik drie keer goud.

Ik heb gezegd. 
Geradpleegde bronnen:

Kennis woor kansen. Prioriteiten van de universitaire branche voor de kabinetsperiode 2002-2006. Position paper Verenging van Universiteten, Utrecht, september 2001.

Kengetallen universitair Onderzoek (KuOz). Vereniging van Universiteten, 30 maat 2001

The Doctors of the Dutch. From Deyman to Donders and Dicke. Irvin M. Modin. Precision Collection of Dutch Medicine, the Netherlands. 